IRSH 49 (2004), pp. I-25 DOI: I0.10I7/S002085900300I $34^{2}$

(C) 2004 Internationaal Instituut voor Sociale Geschiedenis

\title{
Global Factory and Local Field: Convergence and Divergence in the International Cane-Sugar Industry, I $850-$ I 940
}

\author{
ULBE BOSMA AND ROGER KNIGHT
}

Summary: Technological convergence in the international sugar economy began in the i 830 s and was substantially complete by the outbreak of World War I in I9I4. By the end of the nineteenth century, the industrialized sugar factory was a global phenomenon like the steamship and the railway engine (to which key aspects of its innards were closely related). We will argue that the single most important fact about nineteenth-century sugar industries was the degree of technological convergence that came to characterize their manufacturing sectors, regardless of the type of labour involved. A revisiting of the literature of the past twenty-five years, both in the New and Old Worlds, suggests that historians have yet fully to come to terms with the global character of this convergence and with the question of why convergence in the factory had no parallel in the field, where there continued to be a striking global divergence between the means and modes by which the industry was supplied with raw material. This problem in the recent historiography of the subject also highlights issues relating to the "proletarianization" of labour and the assumption that industrial capitalist modernity was inextricably associated with the development of "free labour". More specifically, it draws attention to major flaws in the terms of reference of the now classic debate about the nexus between technological change and the predominant forms of labour in the Caribbean production area. In so doing, it underlines the need for a global rather than simply regional approach to the dynamics of change in the international sugar industry of the late colonial era. The latter part of our article outlines the broad historical parameters of this divergence in the sugar-cane field, and suggests the need for exploring the political economies surrounding the sugar producing areas and their mechanisms of ethnic segmentation of the labour force in particular.

\section{INTRODUCTION}

During the course of the nineteenth century greatly improved technologies of manufacture revolutionized the production of sugar worldwide. Sugar was increasingly manufactured to common industrial standards, assured by a combination of steam and steel and their attendant chemistries. By the opening decades of the twentieth century, in locations as far apart as Taiwan and Louisiana, Java and Cuba, and Hawaii and Natal, the unit of 
industrial sugar manufacture was one in which a common, shared technology was as instantly recognizable as it was later to be in the motor-car plant or oil refinery.

This degree of global convergence in the manufacture of sugar cane into marketable forms of sucrose was not matched, however, by any similar development in the ways in which the industry's raw material was itself produced, nor in the ways in which labour was subordinated to the requirements of that production. This convergence in the factory and divergence in the field forms the fundamental dynamic of the international commodity production of cane sugar during a late colonial era extending from the I85os through to the Great Depression and World War II. The central importance of this dynamic has been largely obscured, nonetheless, by three major flaws in mid- and late twentieth-century historiography of the international sugar economy. We will deal with these below.

First was the (continued) privileging of the Caribbean production area in discussion of the sugar economy worldwide. However, production areas in Asia and the Pacific, and to a lesser extent in Africa, are central to a balanced understanding of the global developments at issue. Specifically, as we shall argue, the fact that for virtually the entire late colonial era the southeast Asian island of Java was the world's second largest single producer of exported cane sugar (after Cuba) is of central importance to an appraisal of the global history of the commodity since the middle of the nineteenth century. Unequivocally, developments in the Caribbean production area did not define the world sugar economy as a whole - and need to be placed in a global setting commensurate with the worldwide character which the commodity production of cane sugar attained during the course of the nineteenth century.

Second was a concentration on developments in the factory, paralleled by an assumption that "the plantation" enjoyed a hegemonic position in the commodity production of sugar. However, "the plantation" as a concept obscures the great variety of ways of raising sugar cane that continued to characterize the international sugar economy throughout the late colonial era. ${ }^{\mathrm{I}}$ They embraced the most rudimentary forms of "peasant" farming through to units of agricultural production that were as industrialized, and as "capitalist" as the factory itself. In this context, the dominance of the "plantation" concept - particularly in its classic form as a centralized unit of "forced" labour - gives a false impression of the existence a single, globally homogeneous, and largely transhistorical unit of production throughout the international sugar economy. In fact, the situation with regard to the means by which sugar's raw material was produced was one of striking and continuing divergence. In turn, it is this

I. Frederic L. Pryor, "Review Article: The Plantation Economy as an Economic System", Journal of Comparative Economics, 6 (1982), pp. 288-301. 
degree of divergence - quite transparent once production areas in Asia and the Pacific, as well as in Africa, are brought into the picture - that underscores the need for a critical appraisal of assumptions that the international commodity sugar industry as a whole witnessed a secular trend toward "proletarianization" during the course of the late colonial era.

Indeed, the third and most important part of our critique relates to precisely these assumptions about the development of labour. As became increasingly clear during a now classic debate (see below), during the nineteenth century the pace of technological transformation in sugar manufacture within the Caribbean production area was largely independent of the prevailing form of labour. Yet the full implications of this conclusion still need to be spelt out. First, we need to assess the extent to which the nineteenth-century "revolution" in sugar production technology was a long drawn out, incremental, and worldwide process, largely conditioned by factors other than the dominant form of labour in any particular locality. Secondly, it subscribes to our argument that the convergence of technologically industrialized manufacture was neither dependent upon, nor paralleled by, any similar trend toward uniformity in either the agriculture of cane or in the forms and organization of labour in the field.

We are not the first, of course, to focus on the difference between "field" and "factory". In his recent book on the American "sugar kingdom" in the Caribbean, for example, César Ayala remarks on both the technological contrast between field and factory, and on the "great diversity of rural producers" incorporated into the sugar complexes of Cuba, Puerto Rico, and the Dominican Republic. ${ }^{2}$ Elsewhere in the book, however, Ayala would appear to gravitate toward the theme of "the emergence of a proletariat" (cf. our critique of this idea), and his discussion does not essay the global framework that underpins the present paper. Important pioneering work on the divergence of "plantation" and "smallholding" forms of production in cane sugar and cotton has been done by Shlomowitz, but it is partially vitiated by the author's assertion that the "plantation" form dominated in cane sugar in all or most major production areas. ${ }^{3}$ In fact, this was far from being the case and, for example, in Cuba and the Philippines (as well as in Taiwan, ${ }^{4}$ which he leaves out of his

2. César J. Ayala, American Sugar Kingdom: The Plantation Economy of the Spanish Caribbean, I898-I934 (Chapel Hill, NC [etc.], I999), p. I 2 I.

3. Ralph Shlomowitz, "Plantations and Smallholdings: Comparative Perspectives from the World Cotton and Cane Sugar Economies i 865-1939", Agricultural History, 58 (1984), pp. II6, 2.

4. Chih-ming Ka, Japanese Colonialism in Taiwan: Land Tenure, Development, and Dependency, I895-1945 (Boulder, CO, I995). 
discussion), the actual arrangements for raising sugar cane were altogether more various. 5 Likewise, the usefulness of his analysis is circumscribed by his apparent assumption that "smallholding" represented a "persisting" rather than a created or revived form of production. ${ }^{6}$ None of this, however, invalidates Shlomowitz's suggestive analysis of why (in some regions) industries may have had a preference for centrally managed production over other forms.

Our own argument, however, is directed, in particular, against attempts to link the growth of a "sugar proletariat" to the evolution of industrialized sugar production. We contend that such attempts are fundamentally misdirected and have obfuscated investigation of the historical, worldwide diversity of sugar's workforce. In line with this, the final section of our paper outlines the broad historical parameters of this diversity.

\section{CONVERGENCE: THE EVOLUTION OF THE GLOBAL SUGAR FACTORY}

The global industrialization of cane-sugar manufacturing that took place during the course of the nineteenth century was conditioned by a great number of factors, including a massive increase in demand for the commodity, new tariff regimes in the main consuming countries, a significant fall in international costs of freight - and the increased extent and penetration of the colonial regimes with which cane-sugar production was closely associated throughout the tropical and subtropical world. In its technological dimensions, however, the key lay in a transformation of manufacture through a combination of steam and steel - and associated applied chemistry - that began to take effect in the I 830 and reached its culmination in the years immediately preceding World War I. ${ }^{7}$

The beginnings of this transformation were to be found in radical

5. See e.g. Ayala, American Sugar Kingdom; J.A. Larkin, Sugar and the Origins of Modern Philippine Society (Berkeley, CA, I993); A.W. McCoy, "Sugar Barons: Formation of a Native Planter Class in the Colonial Philippines", Journal of Peasant Studies, I9 (1992), pp. I06-14I; V.B. Lopez-Varga, The Socio-Politics of Sugar: Wealth, Power Formation and Change in Negros I899-1985 (Bacolod, I989).

6. Shlomowitz, "Plantations and Smallholdings", p. 3.

7. On the nineteenth-century evolution of the industrial sugar factory, see e.g. Noel Deerr, The History of Sugar, 2 vols (London, 1949-1950); Margaret Leidelmeijer, Van Suikermolen tot Grootbedrijf. Technische vernieuwing in de Java-suikerindustrie in de negentiende eeuw (Amsterdam, 1997); Dale W. Tomich, Slavery in the Circuit of Sugar (Baltimore, MD [etc.], 1990); M. Moreno Fraginals, The Sugar Mill: The Socioeconomic Complex of Sugar in Cuba, I760-I860 (New York, 1976). Major contemporary sources include C.G.W. Lock, G.W. Wigner, and R.H. Harland, Sugar Growing and Refining (London [etc.], I882); J.A. Leon, On Sugar Cultivation in Louisana, Cuba etc. and the British Possessions (London, I848); Leonard Wray, The Practical Sugar Planter: Complete Account of the Cultivation and Manufacture of Sugar Cane According to the Latest and Most Improved Methods (London, I848). 
improvements in the milling of sugar cane that began to become internationally widespread from c.I 830 onward, and in the almost simultaneous adoption among cane-sugar producers worldwide of revolutionary techniques in the boiling house which had originated (and were further developed as the century progressed) in the sugar refineries and beet-sugar industry of northern Europe. As far as the grinding of cane was concerned, the crucial advance was the appearance and subsequent continuous improvement of horizontally-set iron or steel crushers, three or more in number, and set in motion by waterwheels or, increasingly and eventually exclusively, by steam engines which, by 1914, were themselves beginning to be replaced by steam or diesel turbines. The eventual result was an almost complete expression of sugar-juice from the cane, something which pre-industrial production techniques had never even approached. The other part of the nineteenth century transformation took place in the boiling house, where cane juice was cleansed of its impurities ("defecated"), reduced to a thick syrup and then, under further heat, brought to the "strike" point at which it could be turned into marketable sugar.

The initial - and crucial - phase of this development, again dating from around I 830, was the development of the (elementary) vacuum pan. The pan largely eliminated the danger of losing sugar through scorching immediately prior to the "strike" by boiling the sugar at a lower temperature made possible by creating a partial vacuum. Subsequently, the new technology of sugar-boiling centred on the application of recirculated steam heat under reduced air pressure throughout what eventually became a continuous process of manufacture. This kind of apparatus, though present in embryo at an earlier date, first came into its own in the I 870 s as the multiple effect condenser (usually referred to as "double", "triple", or "quadruple effet"). In tandem with the vacuum pan, it became the ubiquitous feature of the modern sugar factory. Its arrival had been preceded, moreover, by the centrifuge, in which sugar was "spun" into crystalline form, thus making (largely) obsolete the muscovados, the "clayed" sugar, and all the other diverse products in earlier forms of manufacture. By the end of the century, "centrifugal sugar" had become the commodity's global standard. There followed, in the early I900s, a sequence of substantial refinements throughout the production process, notably an elaborated system of multiple milling, allied to a seemingly equally endless series of improvements in the applied chemistry of manufacture. The main lines of the technological "revolution" in sugar manufacture and its attendant science had already been established, however, before the end of the nineteenth century.

On these technological and scientific foundations, convergence proceeded at an often erratic and globally uneven pace for much of the nineteenth century. In some places the project of technologically 


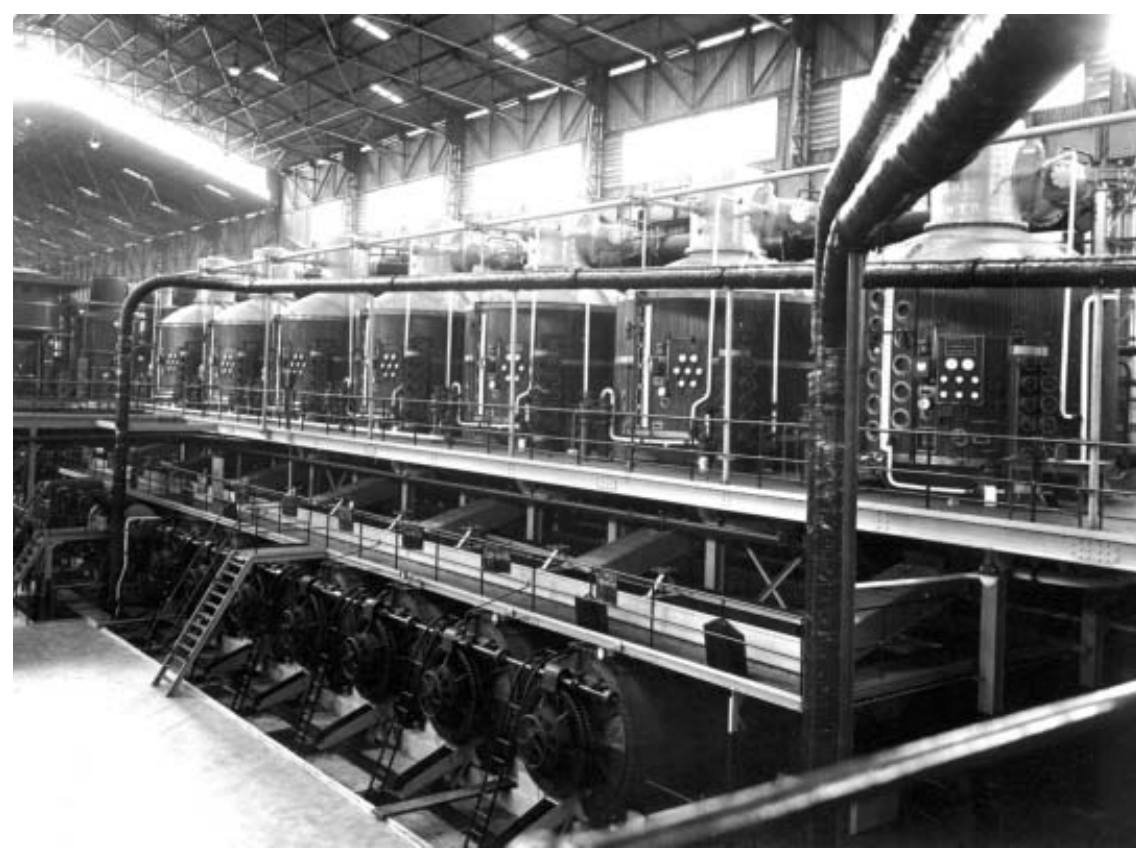

Figure I. The apogee of the global sugar factory in "the East". Interior of the newly built sugar factory, Tjomal Baroe c.1922, showing the multiple effect apparatus in which cane juice was clarified and condensed by recirculated steam heat under reduced air pressure. By the early twentieth century, equipment of this kind was the hallmark of industrial sugar manufacture worldwide.

National Archives, The Hague, Tjomal no. 199; used by permission

industrialized manufacture floundered, as in the Indian subcontinent in the I 840 s, on the seeming rock of existing systems of "peasant" production enmeshed in local merchant capital. Elsewhere, as in Mauritius after the I860s, a "promising" industrial lead evaporated through a paucity of capital for further investment. In sectors of the Caribbean production area, as in Martinique, the existing framework of plantation production retained a rigidity in respect to property relation that prevented the economies of scale necessary, in the longer term at least, to meet the financial requirements of the industrial sugar factory. ${ }^{8}$ Nonetheless, in the New World, most notably in Cuba and in Asia almost uniquely (prior to the twentieth century) in Java, the secular trend toward the industrialization of

8. S. Amin, Sugar Cane and Sugar in Gorakphur (Delhi, I984); Richard Allen, "The Slender, Sweet Thread: Sugar, Capital and Dependency in Mauritius, 1860-1936", The Journal of Imperial and Commonwealth History, I6 (1981), pp. 177-200; Tomich, Slavery in the Circuit of Sugar. 
manufacture worldwide was firmly established from the i 840 s onward. ${ }^{9}$ Toward the end of the nineteenth century, the "global factory" was a dominant presence in both these territories, and was a recent arrival, inter alia, in Australia (Queensland), Hawaii, Guyana, and Puerto Rico. By I9I 4 it had similarly begun to arrive in Taiwan and the Philippines ${ }^{10}$ and in the New World - in Peru, Argentina, and Mexico. ${ }^{\text {II }}$ The process of convergence was worldwide: in a context of sharp international competition, industries that failed the test of technological modernity in manufacturing either collapsed or disappeared into the commercial backwoods of purely local commodity production.

The "classic" debate about the nexus between labour and technology focused on the contention that slavery, which in Cuba remained the dominant form of the labour process until the I880s, formed a significant (though not the sole) obstacle to technological advance within the industry. This was because of inherent contradictions between the rigidity of slave labour and the requirements of machine technology. This was a position most famously associated with the work - in its partial English version at least - of the distinguished Cuban historian Moreno Fraginals. Referring to the mid-nineteenth century advances in production centred on the vacuum pan, he argued that "the new apparatus was too complicated for slaves [...]. Producers now felt the urgent need of labour, which would be cheap, but of a minimal technical level unattainable by slaves. The Industrial Revolution meant the changeover to the wage worker." ${ }^{12}$ Even more succinct was the argument of Franklin W. Knight that "slave labour was woefully incompetent to deal with the scientific advances in the industry". ${ }^{13}$ Transposed, this could then be reformulated as the hypothesis that "the conditions for industrializing the Caribbean sugar economy emerged toward the middle of the century [...] the first was the creation of a rural proletariat". ${ }^{\text {I4 }}$

9. Moreno Fraginals, The Sugar Mill; Leidelmeijer, Van Suikermolen tot Grootbedrijf.

ı. Ka, Japanese Colonialism in Taiwan; Larkin, Sugar and the Origins of Modern Philippine Society.

I I. Bill Albert and A.A. Graves (eds), Crisis and Change in the International Sugar Economy, I860-1914 (Norwich, 1984); idem, The World Sugar Economy in War and Depression 19141940 (London, 1988).

I2. Moreno Fraginals, The Sugar Mill, p. i 2.

13. Quoted in Rebecca J. Scott, Slave Emancipation in Cuba: The Transition to Free Labor, I860-I899 (Princeton, NJ, I984), p. 5 .

I4. C. Schnakenbourg, "From Sugar Estate to Central Factory: The Industrial Revolution in the Caribbean", in Albert and Graves, Crisis and Change in the International Sugar Economy, pp. 83-94, 85. An elaborated and deeply nuanced re-interpretation of the limitations imposed by slave relations of production appeared in Dale W. Tomich's monograph on the nineteenthcentury sugar industry in Martinique; see Tomich, Slavery in the Circuit of Sugar, pp. I 24-I 38. For further important contributions, see e.g. Stanley L. Engerman, "Contract Labour, Sugar and Technology in the Nineteenth Century”, Journal of Economic History, 43 (1983), pp. 635-659; 
In retrospect, these and similar contentions seem largely discredited by arguments from a variety of area specialists that they simply did not fit the facts. Rebecca J. Scott, in particular, demonstrated unequivocally that considerable technological advance in the industry preceded slave emancipation in Cuba in the r880s, and, conversely, that the putative proletarian labour of indentured workers associated with this precocious degree of industrialization was anything but "free". Is Similar arguments have been advanced for much of the rest of the Caribbean production area. ${ }^{16}$ Furthermore, in the specific case of Cuba, it has been convincingly argued not only that industrialization rendered slavery more efficient, as evidenced by increasing slave prices just before abolition, ${ }^{17}$ but also that the high point of slave production in Cuba - that is to say, the middle decades of the nineteenth century - coincided almost exactly with a period of technological advance in manufacture that placed the Spanish colony at the very forefront of the international sugar economy in terms of the "modernity" of its factories. ${ }^{18}$

Within this context, moreover, notions that the new technology was "labour-saving" and in that sense attractive to manufacturers faced with the costs of "free" labour - and, conversely, that an abundance of "cheap" servile labour was a potent disincentive to technological innovation - have largely been laid to rest. ${ }^{19}$ The issue of skilled labour - once confidently

Mary Turner, "Chattel Slaves into Wage Slaves: A Jamaican Case Study”, in Malcolm Cross and Gad Heuman (eds) Labour in the Caribbean: From Emancipation to Independence (London, I988), pp. I4-3I.

is. Scott, Slave Emancipation in Cuba.

I6. Peter Boomgaard and Gert J. Oostindie, "Changing Sugar Technology and the Labour Nexus: The Caribbean, 1750-1900”, Nieuwe West-Indische Gids, 63 (1989), pp. 3-22; Michael Craton, "Commentary: The Search for a Unified Field Theory", Nieuwe West-Indische Gids, 63 (1989), pp. I35-I42; Dale W. Tomich, "Sugar Technology and Slave Labour in Martinique I830-I848", Nieuwe West-Indische Gids, 63 (1989), pp. I 18-134; Michiel Baud, "Sugar and Unfree Labour: Reflections on Labour Control in the Dominican Republic, 1870-1935", The Journal of Peasant Studies, I9 (1992), pp. 301-325.

17. Laird W. Bergad, "The Economic Viability of Sugar Production based on Slave Labor in Cuba, I859-1878”, Latin American Research Review, 24 (1989), pp. 95-I I 3; Laird W. Bergad et al., The Cuban Slave Market: $1790-1880$ (Cambridge, I995); Scott, Slave Emancipation in Cuba.

I8. Oscar Zanetti and Alejandro García, Sugar and Railroads: A Cuban History, I837-1959, Franklin W. Knight and Mary Todd (tr.) (Chapel Hill, NC, I998).

I9. Boomgaard and Oostindie, "Changing Sugar Technology", pp. i I-i s. In particular, it looks as if the labour-saving potential of both the vacuum pan and the multiple effect were altogether less significant than has sometimes been represented. In the case of multiple effect, there certainly was a saving of labour, insofar as several previously discrete manufacturing processes were now brought together in one enclosed set of equipment. The big inducement, however, apart from the potential to produce more and higher-grade sugar from the same quantity of raw material, was a substantial saving in fuel costs in the boiling house, due to the elaborate recirculation of steam heat that previously went to waste. Similarly, the crucial advantage of the vacuum pan - the forerunner of later technological advance in the boiling house - was not that it saved labour but 
cited as the Achilles' heel of systems of slave production - turns out to be equally problematic. The vacuum pan and multiple effect condenser certainly needed experience and judgement in their operation. Any assumption, however, that their adoption was inhibited by slavery and other forms of servile labour seems wide of the mark for two main reasons. First because "servile" expertise is solidly documented and, second, because the number of workers required to operate the new apparatus was quite small, perhaps a score or more: hardly enough to either promote or require a wholesale reformation of the industry's entire labour process.

The centrality to the history of the international sugar economy of the nineteenth and early twentieth centuries of this process of worldwide convergence in the industry's manufacturing sector was nearly lost from sight in the debates about the nexus between labour and technological advance that once dominated the historiography of the subject.

This now "classic" debate, which originated from the assumed obsolescence of slave labour in Cuba, would have taken an entirely different course, if comparisons with the Old World had been essayed from the beginning. Outside the Caribbean, or elsewhere in the New World, the putative link between form of labour and technological advance proves equally difficult to sustain. It was equally the case in Java, Cuba's "Oriental" counterpart in terms not only of the extent of production and export of sugar, but also in terms of a marked degree of parallelism in respect to the forms of labour which predominated there in the mid-nineteenth century decades. Like Cuba for much of the nineteenth century, sugar production in Java was heavily dependent on "forced" labour - but in this case that of conscripted local peasants rather than imported slaves. ${ }^{20}$ No more than in the case of Cuba, however, did this stand in the way of technological advance in the industry's manufacturing sector.

Last but not least, we have to point out that the entire debate could emerge because, twenty years ago, it was difficult to accept that forced labour and capitalist modernity might well be different sides of the same

that it "saved" sugar by preventing scorching in the most critical phase of its manufacture. As Dye remarks: "For someone familiar with the technical requirements of sugar production, it should not be surprising that sugar producers actively adopted advanced industrial technology, despite the lack of strong incentives for labour saving. There were several reasons. First, the innovations were cane saving and fuel saving, and they offered economies of scale far beyond that offered by the older technology [...]. Second, they also reflected the technological interdependence between beet and cane sugar." See Alan Dye, Cuban Sugar in the Age of Mass Production (Stanford, CA, 1998), p. 71.

20. C. Fasseur, The Politics of Colonial Exploitation (Ithaca, NY, 1992); Robert E. Elson, Javanese Peasants and the Colonial Sugar Industry: Impact and Change in an East Java Residency, I830-1940 (Singapore, 1984); idem, Village Java under the Cultivation System (Sydney, NSW, 1994). 
coin. Hence it has often been supposed or implied that the Java industry only began to "modernize" its factories once "forced" labour was phased out in the decades after I 870 and replaced with the "free labour" of local wage-workers. In the case of the sugar industry, however, the evidence on the latter score points to a quite different conclusion: around the mid-century, in the 1850 , the Java industry was among the more technically advanced sectors of the international sugar economy, ${ }^{2 \mathrm{I}}$ and became progressively more so as the century advanced. ${ }^{22}$ As with Cuba, the predominant form of labour did nothing to inhibit technological advance.

21. According to Leidelmeijer, nearly 60 per cent of Java's colonial sugar factories ( 58 in all) were equipped with vacuum pans at c.I857 (Leidelmeijer, Van Suikermolen tot Grootbedrijf, p. I38). No doubt many of these pans were part of "mixed" systems of manufacture that represented a sometimes considerable departure from contemporary international best practice. Yet where was this not the case? In Cuba - to cite the most significant example - where at c.I 860 there were approximately the same number of vacuum pan-equipped sugar factories, similarly "mixed" systems were the order of the day (Moreno Fraginals, The Sugar Mill, pp. 8 I-175). For similar examples from the mid-nineteenth century New World, see J.A. Heitman, The Modernisation of the Louisana Sugar Industry (Baton Rouge, LA, 1987), pp. 3-48, Tomich, Slavery in the Circuit of Sugar, pp. I9I-197. For contemporary confirmation of the prevalence of "mixed" systems - in which vacuum pans operated in tandem with a variety of manufacturing apparatus ranging from the technologically primitive to the relatively advanced, see e.g. Wray, The Practical Sugar Planter, and Leon, On Sugar Cultivation in Louisiana.

22. Only in the r870s did the nineteenth century's second critical technological advance in sugar manufacturing, the multiple effect condenser - usually styled triple or quadruple effet based on the recirculation of steam heat and continuous process defecation and evaporation under reduced air pressure, come into widespread use in colonial sugar manufacture. Prior to that, it had been limited largely to metropolitan sugar refineries because of the scale and expense of its operation; Deerr, The History of Sugar, vol. 2, pp. 565-572; Peter Soames, A Treatise on the Manufacture of Sugar from Sugar Cane (London [etc.], I872), pp. $58 \mathrm{ff}$; Lock, Wigner, and Harland, Sugar Growing and Refining, pp. 269-273. Galloway's usually reliable synthesis of the sugar industry's history is unfortunately poorly informed and confused on this score; J.H. Galloway, The Sugar Cane Industry: An Historical Geography from its Origins to 1914 (Cambridge, 1989), pp. 135-137. Equipment of this kind began to arrive in Java in c.r 877 onward. By the time that the industry was hit by the collapse of world sugar prices in the middle of $\mathrm{I} 884$, at least one-third of the colony's major factories were equipped with multiple effect condensers. See the listing of sugar manufacturing equipment in the Koloniale Verslag (KV) I875-I882. The detailed listing stops in 1882 , however, and in any event is demonstrably incomplete prior to that date. In some key sugar districts, the percentage of multiple effects in use prior to the I 884 was much higher. In Pekalongan-Tegal, the north coast area that accounted for around one-tenth of Java's sugar exports, for example, around two-thirds of the factories were so equipped when the crisis broke. See the information relating to the sugar factories in the Koloniale Verslag (dates refer to year) Pagongan (KV r88I); Adiwerna (KV r879); Doekoewringin (KV I882); Kemanglen (KV I880); Djatibarang (KV I88I); Pangka (KV I878); Kalimatie (KV I878). Other similarly equipped factories were: Balapoelang (Jaarverslag NI Handelsbank (I882), p. IO, Nationaal Archief Handelsbank); Kemantran (Jaarverslag NHM Factorij Batavia (i882), p. 49, Nationaal Archief NHM); Maribaia - a "double effet" (Jaarverslag NHM Factorij Batavia (I883), pp. 5I-52, Nationaal Archief NHM); Klidang (Jaarverslag NHM Factorij Batavia (I883), pp. 5I-52, Nationaal Archief NHM). 


\section{DIVERGENCE: LABOUR, LOCALITY, AND THE RAISING} OF SUGAR CANE

Factory and field were completely interdependent units of production, but the implications of this for developments in the agricultural sector were far from straightforward. Famously, sugar differed from many "colonial" commodities in the degree to which the industry's production of raw material could not spatially be separated from the manufacturing process. Sugar cane was a highly unstable raw material that had to be processed within forty-eight hours of having been cut if a significant fall-off in its vital sucrose content was to be avoided. The factories were all in the immediate proximity of the field, and factory owners were critically aware of the need to ensure a stable supply of cane. In spite of this, however, and in spite of the heavy capital investment and technological precocity that characterized the manufacturing sector, there was only a minimal spread of machine technology to the cane field or plantation. It was limited to the occasional adoption of the steam plough and to the use of rails, and subsequently steam locomotives, in the work of cane haulage. These developments were important, particularly insofar as they related to haulage, where speed and reliability was of the essence. Nevertheless, they were far from universal in major nineteenth-century cane-sugar industries. Even in the early twentieth century, the spread of mechanized cultivation was globally very uneven, and mechanized harvesting was virtually unknown until the interwar decades, and then very rare. In short, although the "revolution" in machine technology may have swept - rather slowly through the factory in the course of the nineteenth century, it stopped short of the field.

Of course, mechanization was only one aspect of the technology of agriculture. Despite some suggestion to the contrary ${ }^{23}$ the nineteenthcentury cane field was not transformed in any of its critical dimensions in a way commensurate with the transformation of the factory. Indeed, what transformation did indeed occur, took place late in the nineteenth century - and then only in a few favoured locations rather than globally. One major, widely accepted index to "modern" agricultural revolution is the intensive use of inorganic, chemical fertilizers: these made little impact in the world's sugar-cane fields prior to the early twentieth century, however, and even then that impact was limited to a small number of industries, Java foremost among them. New and improved methods of cultivation were likewise geographically very limited in extent. This in spite of the heavy interdependence of the sugar industry, and the rapid dissemination of relevant technological innovations among sugar producers across the world. The most celebrated of them, Reynoso's plan for labour-intensive 


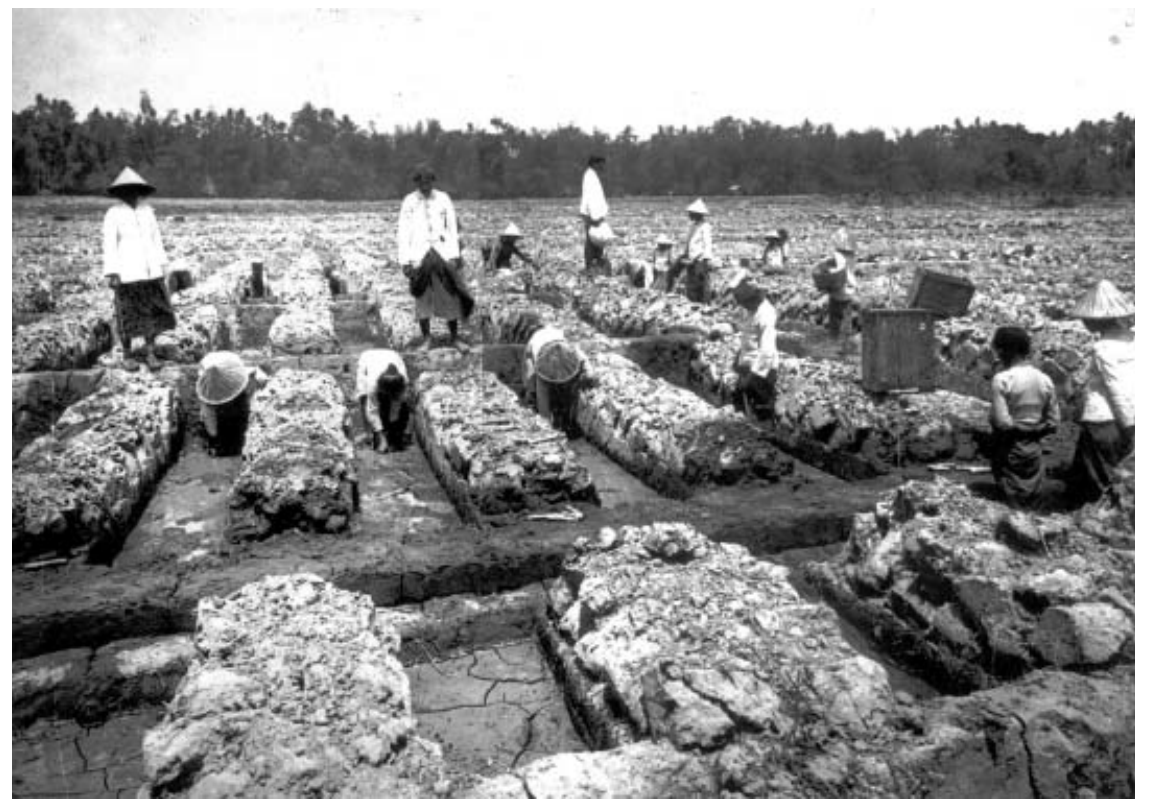

Figure 2. The "industrial plantation" in its internationally most evolved form, in the Dutch East Indies in the I9IOs: the supervision of cane planting in ground opened on the modified Reynoso system used throughout Java from the late nineteenth century onward. Note the use of female labour, the industrial regularity of the plantation, and the equally industrial level of supervision of manual labour. Sugar factory Ketanen, I916.

Royal Tropical Institute, Amsterdam, 633.6I-ISI N2; used by permission

manual trenching of the cane field, devised in the I86os, found little acceptance in his native Cuba or elsewhere in the New World, and was only taken up extensively in Asia - in Dutch Java. ${ }^{24}$ Improvements to drainage and irrigation - further hallmarks of a "revolution" in agriculture - only received spasmodic attention outside a few very specific locations (Hawaii, Java), and the development of new cane varieties had to wait on the work of experimental stations that were still in their infancy in the late nineteenth century.

As a consequence, the "standardized" industrial factory was supplied with its raw material both from "primitive" pre-industrial agriculturists and from plantations on which the most advanced and sophisticated

24. A translation (and adaptation) of the second edition of Reynoso's treatise into Dutch (by J.E. De Vrij and J. Millard), appeared in Rotterdam in I865 (Moreno Fraginals, The Sugar Mill, p. 93). Around 1870 , the Reynoso system of planting appears to have been largely confined to experimental plantings at a very few factories (Kultuur Verslag I87I); by the end of the decade, however, planting according to some version or other of the Reynoso system appears to have been more or less universal throughout north-central Java (Kultuur Verslag I879). 
industrial agriculture was practised, from tenants, share-croppers and "peasant" farmers, and from agrarian entrepreneurs and seigniorial estates: the international sugar economy of the late colonial era was characterized by agricultural technologies and social forms of labour that were anything but homogeneous.

As a result, the cane-sugar industry worldwide counted for its supplies of raw material on a broad repertoire of labour relations and processes. ${ }^{25}$ A clear implication of this degree of divergence is the problematic nature of attempts to depict developments in the workforce in terms of a secular trend toward "proletarianization". In the generally understood sense, the proletariat is composed of workers who are (predominantly) dependent on selling their labour in order to subsist, and who are (notionally) able to sell that labour to the highest bidder - that is say, on a "free market". On a number of related counts, however, the historical reality of "proletarianization" remains fraught with difficulty. One concerns the ambivalence of the "border zone" between "peasants" and "wageworkers", neatly encapsulated in Sydney Mintz's question as to whether, and in what circumstances, it is justifiable to talk of "sometimes peasants" or of "peasants, many of whom had to sell some of their labour" ?26 Another relates to the inelegant but useful concept of "deproletarianization".

The global history of capitalist production, as Brass has repeatedly argued, ${ }^{27}$ shows that such production has frequently relied on its ability to "deproletarianize" the workforce (rather than to "proletarianize" it), by constraining its capacity to bargain with capital and preventing the "free" sale of its labour. This was far from being solely a question of preventing exslaves, as in much of the Caribbean, from becoming too "worker-like". In many Asian production areas (as also in some readings of New World

25. In some instances, sugar cane came from small or relatively small farmers, as in Uttar Pradesh (India), Taiwan, and in some parts of Negros and Luzon in the Philippines - and also in Queensland and Fiji. See Lopez-Varga, The Socio-Politics of Sugar; Ka, Japanese Colonialism in Tairwan; Amin, Sugar Cane and Sugar in Gorakphur; Filomeno V. Aguilar, Jnr, "Sugar Planter: State Relations and the Labour Process in Colonial Philippine Haciendas", Journal of Peasant Studies, 22 (1994), pp. 50-80; A.W. McCoy, "A Queen Dies Slowly: The Rise and Decline of Iloilo City", in A.W. McCoy and E. De Jesus, Philippine Social History (Quezon City, I982), pp. 297-360; McCoy, "Sugar Barons"; A.A. Graves, Cane and Labour: The Political Economy of the Queensland Sugar Industry I862-I 906 (Edinburgh, I993). Elsewhere, as was partly also the case in Negros and Luzon, mills might buy cane from substantial "estates", often the remnants of an earlier, plantation-based system of manufacture. In the "American" Caribbean, as Ayala demonstrates conclusively, the dominance of centralized manufacture went hand in hand with a great diversity of arrangements for producing the industry's raw material; Ayala, "Social and Economic Aspects of Sugar Production in Cuba".

26. Sidney W. Mintz, "Descrying the Peasantry", Review (Binghampton), 6 (1982), pp. 209228, 222.

27. Tom Brass, "Introduction: Free and Unfree Labour: The Debate Continues", in Tom Brass and Marcel van der Linden, Free and Unfree Labour: The Debate Continues (Bern, 1997), pp. I I -42 . 
developments) it was question of preventing peasants from doing likewise. In Bernstein and Brass's formulation "the object [...] was not to force a long-standing $[\ldots]$ peasantry to become workers [...] as much as to stop precisely just such a transition from taking place: that is, to prevent/ preclude a de facto proletariat from becoming, continuing or acting as such". ${ }^{28}$

But while the concept of deproletarianization covers a broad range of changes in labour relations and unites in that respect the Old and New Worlds in a single analytical framework, it does have its limitations. First, it too easily excludes the way in which labour costs, technology, and the availability of land were traded off against each other as part of the analysis. Secondly, demands by labour were also met with (ethnic) segmentation of the labour force and this process can be attended by but is certainly not equivalent to - deproletarianization. We shall return to this issue after having first essayed a restatement of the "problem" in an analysis of field production in the cane-sugar industries of the late colonial era, a restatement fleshed out by reference to the contrasting sugar complexes of Cuba and Java.

\section{DIVERGENCE: THE SUGAR COMPLEX IN JAVA AND CUBA}

The sugar factories of Java and Cuba, both in the mid-nineteenth century decades and subsequently, bore a close resemblance to each other in terms of their technological modernity, even though by the r9ios and I920s the Cuba factories were substantially larger units of production. At that point, however, all resemblance ended. The agricultural sectors of the two industries could hardly have been more different, in terms both of the agriculture of cane itself and of the agrarian context in which it was produced. A brief comparison of the two industries is hence relevant not only to the two producers concerned but also to an understanding of divergence worldwide: though Java and Cuba stood at extremes, the differences between them were reflected, to a greater or lesser degree, in virtually every other significant contemporary production area.

The Java sugar factory was a free-standing entity, largely devoid of plantations of its own - and yet characterized by a degree of direct management of cane cultivation that was rarely encountered elsewhere in the international sugar economy of the late colonial era (Hawaii and Peru being the only major exceptions). This apparent paradox is explained by the way in which the commodity production of sugar was renewed in midnineteenth century Java under the aegis of the Cultuurstelsel (System of [State] Cultivations) and by the extent to which the matrix of production

28. Tom Brass and Henry Bernstein, "Introduction: Proletarianisation and Deproletarianisation on the Colonial Plantation”, Journal of Peasant Studies, I9, 3-4 (1992), pp. I-40, I7. 
which it created survived the demise of the Stelsel itself in the course of the I 88 os. ${ }^{29}$

The Cultuurstelsel was designed by the Dutch colonial government in the Dutch East Indies in c.I 830 to procure commodities for export from the land and labour of the Javanese peasantry. The way in which the industry was set up was that each factory which contracted to the East Indies government to manufacture sugar (in C.I 850 there were nearly ioo such) was assigned a procurement zone (Beschikkingskring) among the neighbouring villages, from which it drew both sugar cane and labour which were made available to through a system of forced labour. Sugar cane was rotated annually around village rice fields in a system of shifting cultivation. There was no "plantation" in the sense of land permanently assigned to cane and alienated long-term from other cultivation. This arrangement remained the hallmark of cane cultivation in Java throughout the late colonial era, though with the phasing out of the Cultuurstelsel (completed in this respect in c.r 890), cane was grown on village farmland rented by the factories and worked by wage labour, rather than as a form of compulsory cultivation imposed on villagers by state officials.

The upshot was to create a factory-and-field complex that was virtually unique to the Java industry. It was one, moreover, whose flexibility meant that units of production could be enlarged to meet the requirements - both in terms of the amounts of raw material consumed and the economies of scale necessitated by the expense of the equipment involved - of the fully industrialized manufacture of sugar that became de rigeur, from at least the I 870 s onward, for industries that hoped to remain competitive on the world commodity market. In that sense, the Java manufacturers were able to follow the process of industrial convergence (described above) without the major restructuring of the industry that was the sine qua non of fully industrialized manufacture in many rival production areas. The network of factories created in the mid-nineteenth-century decades was subsequently added to (and some factories went out of production), but it was neither

29. On the Java sugar complex of the period I830-1940, see e.g. P. Boomgaard, "Treacherous Cane: the Java Sugar Industry", in Albert and Graves, The World Sugar Economy in War and Depression, pp. 157-169; Elson, Javanese Peasants and the Colonial Sugar Industry; idem, Village Java under the Cultivation System; "Peasant Labour and Capitalist Production in Late Colonial Indonesia: The Campaign at a North Java Sugar Factory 1840-1870", Journal of Southeast Asian Studies, 19 (1988), pp. 245-265; idem, Colonial Production in Provincial Java: The Sugar Industry in Pekalongan-Tegal, I800-1942 (Amsterdam, I993); idem "The Visible Hand in Tempo Doeloe: The Culture of Management and the Organisation of Business in Java's Colonial Sugar Industry", Journal of Southeast Asian Studies, 30 (1999) pp. 74-98; idem, "The Sugar Industry of Colonial Java and its Global Trajectory", South East Asia Research, 8 (2000), pp. 249-274; G. Roger Knight and Arthur van Schaik, "State and Capital in Late Colonial Indonesia", Bijdragen tot de Taal-, Land-en Volkenkunde, I 57 (200I), pp. 83 I-859; Robert Van Niel, Java under the Cultivation System (Leiden, I992). 
suppressed nor rendered obsolete by the industrialization process. One consequence of this was that the system of central factories - decentralized production of raw material, in which one centrale processed cane from a variety of different producers - never took hold in Java.

As a result of this, the Java factory's control over its supply of raw material was and remained virtually complete. Although peasant "outgrowers" participated in colonial sugar production in some few parts of Java (and then only for a few decades), most of the cane crushed by Java's colonial-owned sugar factories was grown under the direct management and supervision of the factory's own employees on rented land using hired labour. Labour was relatively freely and cheaply available - especially, from the late nineteenth century onward, that of women and children. Land, however, was at a premium in Java, where a rapidly growing population meant that the opportunity cost of devoting land to cane was both high and rising. Familiarity of Dutch owners and managers with agricultural practices in the sugar-beet fields of northern Europe (particularly those of Germany and Holland itself), led to the adoption in Java, late in the nineteenth century, of a programme of intensive fertilizer application in the colony's cane fields that was totally without parallel internationally..$^{\circ}$ In conjunction with plant selection, irrigation, pest control, and a "research and development" record that placed the industry at the apex of world best practice, Java achieved a level of field productivity (cane yields per hectare) that was substantially in advance of all its competitors. ${ }^{3 \mathrm{I}}$

30. By the eve of World War I, Java was the world's seventh largest consumer of sulphate of ammonia, the key inorganic fertilizer used on cane (and sugar beet). In Asia, only Japan exceeded this level of consumption, and no other "sugar colony" in the world was listed as a significant consumer. See W.J. van der Leemkolk, “Gebrek van Meststoffen”, Tijdschrift voor Nijverheid en landbouw in Nederlandsch Indie, 92 (I91 5), pp. 99- I I3, I I I. Between I 900 and the early I930s, at many of Java's colonial sugar factories, the cost of fertilizer (mostly imported sulphate of ammonia) accounted for around 20 per cent (or more) of total "plantation" costs per hectare (i.e. a total made up of employee costs, labour costs, land rental, and the cost of cane cuttings (bibit) etc. For further discussion on this score, see G. Roger Knight, "Exploding the Myths: Industrial Fertiliser and the Agricultural Revolution in the Cane Fields of late Colonial Java", (forthcoming).

3I. The approximate figures (tons cane per ha.) for plantation yields for the five-year period I908/1909-I9I 2/I9I3 are: Java I08; Hawaii 89; Cuba 43; Queensland 4I; Louisiana 36; Taiwan 28 (calculated from FAO, The World Sugar Economy in Figures I880-1959 (Rome, I96I), pp. 33); Philippines production is absent from this source and other Caribbean production data is incomplete for the period in question. Data from Albert and Graves, The World Sugar Economy in War and Depression, p. 79, for I9I 8 suggests that early twentieth-century Peru was not far behind or even the equal of Java in terms of plantation yields (1918 = 107.5 tons per ha.). However, the apparently comparable high plantation yields in Hawaii and Peru are not what they seem: they have to be set against an eighteen-month to two-year growing period for cane, substantially longer than the twelve to fifteen months that was standard in Java: i.e. over the same period of time, the Java industry produced much more sugar per hectare than its Hawaii or Peru counterparts. See E.D. Beechert, "Technology and Plantation Labour Supply", in Albert and 
It was not only high yields, moreover, that set the Java industry apart: productivity was itself a reflection of the extent to which the cane fields of late colonial Java had themselves become highly industrialized units of production, in terms not only of agricultural technique and horticultural practice but also in terms of the industrial work routines and industrial discipline imposed upon the workers. Whether or not the workforce available to the bulk of Java's sugar producers was "proletarian" is largely irrelevant: the key point was that the industry could transform it into the basis for industrial field production. The hallmark of such production in Java was not mechanization (which played a secondary role largely limited to the haulage of cane)..$^{32}$ Instead, it was the intensive exploitation of a regimented, task-differentiated workforce that was generally paid at taskrates and which almost always worked under a highly elaborated system of supervision. Contemporary accounts give a very full narrative of the meticulously planned and minutely regulated nature of fieldwork as it came to be practiced in Java. ${ }^{33}$ In terms of manufacturing, the Java sugar complex "converged" during the nineteenth and early twentieth centuries on what became a common, global pattern. In respect to the agricultural sector, however, it "diverged" - in many respects in a quite spectacular fashion.

In Cuba, the agricultural sector (at least post-emancipation in the I 880 ) developed in an entirely contrary direction. The social and technological configuration of the Cuban sugar complex is, of course, much better known than its Java counterpart. The Cuba industry, already long established, came to international prominence in the mid-nineteenth century, in the wake of the great rebellion in Haiti late in the I790s. From the first decade of the nineteenth century onwards, the massive introduction of slaves and the early application of steel and steam were its outstanding features. It overtook Brazil as the Western hemisphere's

Graves, The World Sugar Economy in War and Depression, pp. I3 I-I41, I36; Bill Albert, An Essay on the Peruvian Sugar Industry 1880-1920, and The Letters of Ronald Gordon, Administrator of the British Sugar Company in the Canetee Valley, 1914-I9I9 (Norwich, 1976), pp. 25, 91.

32. The Java sugar plantation was a precocious variant on the East Asian model of labour intensive industrialization, on which, see, e.g., Kaoru Sugihara, "Agriculture and Industrialization: The Japanese Experience", in Peter Mathias and John Davis (eds), Agriculture and Economic Growth (Oxford, I996), pp. I48-166. That is to say, compared to "classical" industrialization, it absorbed and utilized labour more fully - and depended less on the replacement of labour by machinery. In acknowledging the different conditions of factor endowment prevailing in late colonial Java, it recognized that both land and capital were in short supply but that labour was not. In consequence, it aimed at the maximum and most effective use of labour wherever capital and labour were substitutable.

33. S.C. van Musschenbroek, "Beknopt Overzicht der Rietcultuur op de Onderneming Tjomal", Het Archief voor de Suikerindustrie in NI, I0 (1902), pp 52 I-540; J. Sibinga Mulder, De Rietsuikerindustrie op Java (Onze Koloniale Landbouw: I) (Haarlem, I929). 
largest single producer of cane sugar. Whereas Java's colonial sugar factories were by that date divested of formal plantations, and were embedded within a much larger "peasant" agrarian formation, those of Cuba existed within the very epitome of a plantation regime, characterized (predominantly) by slave-worked sugar estates which dominated the island's agriculture. In Cuba's western districts, at least, the bulk of good agricultural land had always been assigned to sugar and other plantation crops, and the mass of the working population had been settled there (predominantly as slaves prior to final end of slavery in I 886) precisely to cater to the requirements of commodity production.

From the I 840 on onwards, the Cuba industry famously began to develop an "advanced" manufacturing sector, which reached its apogee late in the nineteenth century with the appearance of centrales. These enabled the industry to cope with what one recent writer has dubbed the dawning "age of mass production", 34 by concentrating manufacturing in large units, no longer dependent on a single estate to supply them and drawing their raw material from multiple sources. Contemporaneously, the labour process in Cuban sugar production shifted from slavery, which was abolished in I 886, via various forms of indenture through to wage labour, expressed in a wide variety of forms. Wage labour, however, was subordinated to the requirements of sugar production in a very different fashion than in Java. In Java the direct farming of cane with wage labour practised by the overwhelming majority of factories was one of the keys to high field productivity. In Cuba, on the other hand, direct farming of this kind, though not unknown, played a minor role in an industry characterized primarily by a dichotomy between centrales and colonos or cane growers themselves often the employers of labour rather than direct producers who existed in varying degrees of (in)dependency on the mill owners. ${ }^{35}$ Obviously, the colonos did not have the means to mechanize their production.

Indeed, by far the most striking contrast between Java and Cuba by the close of the nineteenth century related to the agricultural sector of production. Agriculture was famously "neglected" - though in a manner that well-placed contemporaries judged to be economically rational. ${ }^{36}$ Around the beginning of the twentieth century, agricultural yields (sugar cane per hectare of plantation) in Cuba either declined or remained stationary, ${ }^{37}$ at a time when the global trends in agricultural yields was for them to rise. Research and development in the agricultural sector of production was almost nonexistent. Cuba's industrial yields (sugar per ton of cane), on the other hand, were among the world's most formidable,

34. Dye, Cuban Sugar in the Age of Mass Production.

35. Ayala, American Sugar Kingdom, pp. I83-2 I I.

36. Dye, Cuban Sugar in the Age of Mass Production, p. 24I.

37. Ayala, "Social and Economic Aspects of Sugar Production in Cuba", pp. 104-106. 
reflecting the high quality of the Cuba factories and their level of technological perfection. Taken together with the economies of scale inherent in the size of the Cuba factories (in terms of milling capacity they were the world's largest) meant that the Cuba industry appears to have been able to produce sugar as cheap as - or indeed cheaper than - any of its international counterparts. ${ }^{38}$

\section{EXPLAINING DIVERGENCE: THE POLITICAL ECONOMY OF SUGAR PRODUCTION}

The comparison between Java and Cuba demonstrated a wide divergence with respect both to the techniques of cultivation and the way in which labour was subordinated to the requirements of cultivation. Three factors have been suggested to explain this divergence: supplies of labour, availability of land, of capital, and availability of technology. We will deal with these factors and turn to the respective political economies of the two largest sugar producers.

To begin with the availability of technology. Neither Java nor Cuba had recourse to mechanization in the field. Technology was clearly not in the driving seat: it was not the presence or absence of appropriate technologies per se that explained global divergence in the agricultural sector. As far as the field was concerned, the crucial issue is mechanized cultivation. From the mid-nineteenth century, mechanized cultivation in the form of the steam plough was "available" and in experimental use worldwide, in both the New World and the (Asian) Old. Only in a few localities, however, did manufacturers get serious about mechanical cultivation. It might be supposed, of course, that in others the adoption of the Reynoso system - which largely replaced ploughing with trench digging - might have slowed the rate of mechanized cultivation by posing new challenges. Perhaps so, but in Java the sugar factories experimented throughout the I9IOs and I920s with mechanical trench diggers, without ever adopting them on any significant scale. Nor would it seem that the availability or otherwise of capital was a vital clue. Leastwise, the Cuba industry stands out globally as being the world's potentially heaviest capitalized - thanks to its intimate connections with United States capital - and also one of the most agriculturally "underdeveloped". The underlying problem with positing technology and its availability to particular industries as a critical determinant of divergence, however, is that the industrial plantation was not predicated primarily or necessarily on mechanization. As already described, the essence of industrial agriculture, as we have set out to define it, was predicated instead on the subordination of labour and its 
organization into a closely supervized, task-differentiated and often racially segmented body of disciplined workers. Sugar industries worldwide were only rarely able to achieve this. Java represented the apogee of such development. Hawaii and Peru - both much smaller industries approached this "ideal" in some respects, the first with a largely indentured, migrant workforce. ${ }^{39}$

If not technology and capital, then how far does the availability of labour itself go toward explaining divergence in the agricultural sector? Famously, it struck late colonial contemporaries that Java had a significant edge over Cuba and all other major cane-sugar exporters by virtue of its "cheap" and "available" labour. While the Java industry had to cope with a limited area designated for sugar cane but almost unlimited supplies of labour, Cuban land was providentially fertile and there was plenty of it, whereas labour was expensive and in limited supply. Within the context of the world market, the lower opportunity costs of land in Cuba were offset by lower field-labour costs in Java. ${ }^{40}$ Typically, Cuban plantations economized on labour through ratooning their cane (i.e. allowing regrowth from the roots left in the ground after the harvest), a practice which meant that cane only had to be planted once in six or seven years as opposed to the annual replanting that took place in Java. It resulted in declined yields of cane but significant economies in respect to labour. Taken in isolation, however, labour inputs do not explain very much. In Java, the relative availability of labour was used to sustain a programme of industrialized agriculture based on the intensive application of fertilizer, industrial work-routines in the plantation, advanced agricultural technologies, close attention to irrigation (and an enviable degree of control of the scarce resource of water!) - all salted by a substantial amount of research and development in the agricultural sector.

Neither the evolution of this situation nor that of the profoundly dissimilar one in Cuba can be explained without constant reference to the historical - and hence changing - political economy of the production areas concerned. As Beechert remarks with reference to Hawaii:

$[\ldots]$ when sugar producing areas are compared on the points of labour supply and deployment and technological development, factors other than the basic plantation system are responsible for the observable differences. The different plantation systems derive from ecological factors and political economies rather

39. John M. Lui, "Race, Ethnicity and the Sugar Plantation System: Asian Labor in Hawaii, I $850-1900$ ", in Lucie Cheng and Edna Bonacich, Labor Immigration Under Capitalism: Asian Workers in the United States before World War II (Berkeley, CA, I984); Edward D. Beechert, Working in Hawaii: A Labor History (Honolulu, HI, 1985); Albert, An Essay on the Peruvian Sugar Industry, p. I9.

40. Dye, Cuban Sugar in the Age of Mass Production, pp. 242, 245. 
than from the factors of labour supply and [the availability of] technology [emphasis added]. ${ }^{\mathrm{I}}$

In short, if we are to understand divergence in the agricultural sector of sugar production worldwide, it is the varied, historical configurations of colonialisms and of (quasi-) colonial states that need to be spelt out. ${ }^{2}$

Let us therefore have a closer look at the completely divergent patterns of labour movements in Cuba and Java. In both cases the industries were owned by overseas investors. In Cuba, American owners had as much interest as their Dutch and Dutch colonial counterparts in trying to curb the labour unions and lower the wages. But here the situation became totally different from Java. Their attempts to deproletarianize at least part of their labour force met with stiff opposition. Former slaves, their descendants, and Spanish migrant labour imbued with anarchist ideas gave the Cuban labour force on the plantations a particularly resilient and classconscious rather than race-conscious character. About 800,000 Spanish migrants (including from the Canary islands) entered Cuba between 1902 and I93 I, many of them as seasonal labourers, but not as a deproletarianized type of labour. 43 The Afro-Cubans who had participated in the independence struggle were strongly aware of their citizen rights. Attempts of their employers to prevent them from associating, culminating in a brutal repression in I9I 2 , did not break their resilience. ${ }^{44}$ Cuban white dominated nationalism and its labour movement's multiracialism opposed the United States dominated sugar industry to restructure its labour force by replacing free workers with unfree equivalents, as according to Brass and Bernstein, "such a restructuring enables planters first to lower the costs of local workers by unfree, more easily regulated, and thus cheaper outside labour". ${ }^{45}$ Eventually, the sugar industry forced the Cuban government to abandon its "white-only immigration" policies and cheap labour was found on the neighbouring island that was divided between the immensely poor republic, Haiti, and the Dominican Republic. More than 300,000 immigrants from Jamaica, Puerto Rico, Barbados, Grenada, Aruba, Curaçao, and particularly from Haiti, entered Cuba between I917-I93 I, to be employed more or less as a second-rate, and

4I. Beechert, "Technology and Plantation Labour Supply", p. I 32.

42. A notable attempt to do so for parts of the Caribbean is Ayala, American Sugar Kingdom, pp. I $48-$ I 82 .

43. Alejandro de la Fuente, "Two Dangers, One Solution: Immigration, Race, and Labor in Cuba 1900-1930", International Labor and Working-Class History, 5 I (1997), pp. 30-49.

44. Rebecca J. Scott, "Defining the Boundaries of Freedom in the World of Cane: Cuba, Brazil and Louisiana after Emancipation”, American Historical Review, 2 I (1994), pp. 70-I02; Rebecca J. Scott, "Fault Lines, Colour Lines and Party Lines: Race, Labour and Collective Action in Louisiana and Cuba, I962-I9I 2", in Frederick Cooper, Thomas. C. Holt, and Rebecca J. Scott (eds), Beyond Slavery (Chapel Hill, NC, 2000), pp. 61-105, I03.

45. Brass and Bernstein, "Introduction: Proletarianisation and Deproletarianisation", p. I7. 
lower-paid, labour force. ${ }^{46}$ However, multiracialism was strongly embedded in the Cuban labour movement. In short, US-dominated sugar industry put all its weight behind a restructuring of the Cuban labour force, which had to some extent the effect of depressing wages, but it met too much political opposition to enforce a racial segmentation. ${ }^{47}$

In the context of this argument, our contention is that the sugar industry maintained a broad repertoire of labour relations, and that segmentation of the labour market was a crucial instrument in the age of labour unionism. But not all historical and political configurations are conducive to segmentation. Racial segmentation was a marked feature of the Java sugar industry; it was also rigidly present in the Dominican Republic, whereas on the adjacent island of Cuba class often overrode race or, later on, the divide between Afro-Cubans and Caribbean immigrant labourers..$^{8}$ The role of the state with regard to labour relations in the sugar industry showed a marked degree of differentiation throughout the various sugar economies. In fact, industry-state relations extended across the whole gamut of possibilities. At one end, as in Java and the Dominican Republic, the industry was largely successful in imposing its will upon the state. At the other end was a stand-off between capital and labour, as in Nicaragua, Argentina, and Mauritius - a stand-off which, at its most extreme, resulted in the state taking over, or at least regulating, the sugar industry, as was the case, eventually, in Mexico and Cuba. ${ }^{49}$ Employers in the Dominican Republic $^{50}$ and Java could rely on the (colonial) state to maintain a racial segmentation of the labour market, and thus splinter labour unionism, whereas the Cuban sugar industries were confronted by a nationalist elite that was suspicious about US interests and a labour movement that began to cross racial and national boundaries.

In view of the abundant availability of labour, and the Java sugar industry's enormous economic muscle, it is not surprising that the employers could impose an effective resistance to labour unionism on the colonial state. This was demonstrated almost immediately after World

46. Dye, Cuban Sugar in the Age of Mass Production, pp. 54-56; Baud, "Sugar and Unfree Labour", p. 309; Barry Carr, "Identity, Class and Nation: Black Immigrant Workers, Cuban Communism, and the Sugar Insurgency, 1925-1934", The Hispanic American Historical Review, 78 (1998), pp. 83-16, 93.

47. Scott, "Fault Lines, Colour Lines and Party Lines", p. ı०3.

48. Carr, "Identity, Class and Nation", p. i is.

49. Peter Singelmann, "The Sugar Industry in Postrevolutionary Mexico: State Intervention and Private Capital", Latin American Research Review, 28 (1993), pp. 6I-88; Jeffrey Gould, "Por su resistencia y pericia: Las relaciones laborales en el ingenio San Antonio (I9I2-I926) (Nicaragua)", Anuario de Estudios Centroamericanos, I 3 (1987), pp. 25-42; Daniel J. Greenberg, "Sugar Depression and Agrarian Revolt: The Argentine Radical Party and the Tucuman Cañeros Strike of 1927”, Hispanic American Historical Review, 67 (1987), pp. 30 I-327.

50. Baud, "Sugar and Unfree Labour", pp. 314, 3 19. 
War I, in I9I9, when sugar prices and windfall profits, that the industry was known to be enjoying, had encouraged Indonesian factory staff to establish their own labour union, the Personeel Fabriek Bond (PFB). The employers withstood pressure from the colonial government to recognize the PFB and nipped in the bud an alliance between European and Indonesian unionism. Anxious to preserve ethnic segmentation, employers resisted successfully any labour unionism of Indonesian workers. A perfect integration of field and factory management was counterbalanced by a rigid segmentation of the labour market between European citizens and Indonesian subjects. Soon, the heavy hand of the state stretched out to the railways, which played a strategic role for the sugar industry. In 1923 the militant railway union was effectively curbed just before the sugar campaign. ${ }^{\text {I }}$ Repression of labour unionism was considered to be vital for the survival of the sugar industry and consequently for the colonial state.

It was the structure of colonial society that was established during the cultivation system that had enabled Java sugar employers to keep their workforce segmented and hence to curb labour unionism. This created a climate favourable to consistent deproletarianization, whereas on Cuba there existed a secular trend towards proletarianization. Though the sugar boom of World War I had allowed Cuban employers to import labour from other Caribbean islands, they also had to accommodate labour. Moreover, the seasonal Caribbean migrant labourers - only is per cent was permanently employed in sugar - soon became more or less permanent residents, finding work, during the prosperous I920s, in urban areas after the work in the field was done. This proletarianized stratum was mobilized by communist-dominated labour unions, which took a principled stance against racial discrimination. They were successful, in spite of the fact that the government's anti-immigrant legislation of 1933 pandered to the anxieties of the economically vulnerable Afro-Cubans. The communist-dominated sugar labour union stood united against the expulsion of Caribbean labourers by the Cuban government..$^{2}$ Eventually, a complete regulation of prices, wages, and production quotas was adopted by the Batista regime in 1937 and American capitalists gave way to a reCubanization of the sugar industry.

The two largest producers of cane sugar went through historical trajectories that were almost poles apart as regards the configurations of labour, capital, and the state. However, proletarianization or deproletarianization per se were not the key mechanisms at play in establishing this contrast. Instead, the key lay in the potential for segmentation of the labour market, something which is predicated upon the racial and political structure of society at large. Both industries successfully calibrated

5. Ulbe Bosma, Karel Zaalberg. Journalist en strijder voor de Indo (Leiden, I997), p. 369.

52. Carr, "Identity, Class and Nation", p. i I 5. 
mechanization and input of labour, but the Cuban industry was not successful in "deproletarianizing" its seasonal labour force. In the age of mass production it could not prevent proletarianization and not always curb "labour's demands", particularly not at times when sugar prices were high and/or labour was scarce. In these contexts the way in which employers and the state could invoke ethnic or racial boundaries determined the different trajectories of Java and Cuba. We agree with Dale Tomich that the production of sugar allows for "huge comparisons", which promise to offer us relevant insights even for late twentieth-century patterns of labour segmentation in a global economy. 53

\section{CONCLUSION}

Our argument in this article has been for the need to advance discussion of sugar, labour, and technology in the late colonial era beyond the concerns voiced in a now classic debate largely carried on with reference to the Caribbean and other New World production areas. We began our paper by contending that the "classic" debate is substantially vitiated by misplaced assumptions about the technological "revolution" in sugar production during the nineteenth century, and by a parallel failure to examine closely enough the forms of labour associated with sugar in the late colonial era.

The progress of technological advance through the international sugar economy during the nineteenth and early twentieth centuries has a complex and often ambiguous history that is not easily reconciled with changes in the prevalent labour process. In the factory, an essentially incremental "revolution" took place over the better part of a century - one that was only tenuously connected with a transition to "free labour". In the field, there was no necessary equivalence between field mechanization and the industrialization of agricultural production. Indeed, as the case of Java illustrates, the agriculture of cane might reach its most evolved industrial form in the almost total absence of machine technology. Nor was there any global tendency for sugar's field workforce to be transformed into a proletariat.

The nub of our argument, however, concerns the history of convergence in the factory and divergence in the field that characterized cane-sugar production globally during the late colonial era. By the end of the century, advanced sugar factories globally exhibited a fundamental similarity in respect to the equipment they housed, ranging from cane-feeders and mills at the beginning of the production line through to the bank of centrifuges turning out crystalline sugar at its end. Factory workforces also came to 
display similar, albeit not identical, "industrial" characteristics. No similar convergence, however, took place in the agricultural sector. There was no parallel underlying global homogeneity in how the industry's raw material was produced. The social forms taken by field production, as well as field productivity, were extremely varied: in this sector of production, as distinct from manufacturing, sugar globally was characterized by a broad repertoire of labour relations. 